\title{
Restoration of natural capital: Mobilising private sector investment
}

\author{
James N Blignaut ${ }^{1} \&$ Leandri van der Elst ${ }^{2}$
}

\begin{abstract}
This research aims to provide an analysis of the private sector's potential contribution to the maintenance of ecosystem services in South Africa. While there is widespread support for payment for ecosystem services and goods (PES), the development of markets and the making of payments are heavily constrained by a number of factors. This constraint is because there are barriers to entry and the need to facilitate the market-making process. This process could be supported by, among others, the establishment of a PES stimulation fund. It is unlikely that the PES potential would be realised without such high-level intervention and support. The fund has a very important role to play in assisting the development of the PES industry in South Africa. Its development enjoys overwhelming support, and the role of a financial intermediary is central to the success of PES.
\end{abstract}

Keywords: natural capital; ecosystem; payment for ecosystem services and goods; market-making process; private sector

\section{Introduction}

The commercial private sector is arguably the most dominant sector with respect to the use and transformation of natural capital, both renewable and non-renewable natural resources. This use and transformation often leads to the degradation of natural capital. Such degradation reduces the capacity of the degraded landscape to produce a constant and sustainable flow of ecosystem goods and services, both in the current time period as well as for future generations. Therefore, it goes without saying that, without even considering any financial and economic considerations, there is a moral obligation to restore degraded natural capital. This implies that companies should, as a standard activity, invest a portion of their proceeds in the restoration of natural capital. Their historic and current use of natural capital could be considered a loan from future generations, hence the need to invest in restoration to ensure the sustainable flow of ecosystem goods and services in future. The principle of investing in the restoration of natural capital is embedded within the capital theory approach to economic development (Hicks, 1946). This theory's underlying principle is 'to keep capital intact'. This implies that a portion of the proceeds from using a resource and/or capital has to be ploughed back in revitalising or replenishing the stock. This well-established principle is implemented practically by companies and accountants worldwide by what is known as a depreciation allowance. Prudent and forward-looking companies will not use its depreciation allowance on consumables, but will set such monies aside for reinvestment to ensure the non-depletion of the capital stock. That is the true meaning or intent of development that will last. This is eloquently articulated by Hicks as follows:

\footnotetext{
${ }^{1}$ Professor, Lecturer and Director of ASSET Research, Department of Economics, University of Pretoria, PO Box 144, Derdepark 0035, South Africa. Corresponding author: jnblignaut@gmail. com

${ }^{2}$ Team member, ASSET Research \& Beatus, PO Box 144, Derdepark 0035, South Africa.
} 
The purpose of income calculations in practical affairs is to give people an indication of the amount which they can consume without impoverishing themselves. Following out of this idea, it would seem that we ought to define a man's income as the maximum value which he can consume during a week, and still expect to be as well off at the end of the week as he was at the beginning. Thus, when a person saves, he plans to be better off in the future; when he lives beyond his income he plans to be worse off. Remembering that the practical purpose of income is to serve as a guide for prudent conduct, I think it is fairly clear that this is what the central meaning must be. (Hicks, 1946:172)

Ensuring the non-depreciation of a country's natural capital stock is no different from its physical or constructed capital stock (Costanza \& Daly, 1992; Daly, 1996; Stern, 1997). El Serafy (1989:11) compares consumption of income and capital as follows:

The fundamental principle that is flouted by applying conventional national income accounting to depletable resources is the separation that must be maintained between income and capital. This principle tells us that if you liquidate your assets and use the proceeds for consumption, you are living beyond your means, and in doing so you are undermining your ability to create future income. (El Serafy, 1989:11)

The World Bank goes even further in stressing the importance of securing and ensuring the capability of capital stocks for wealth and sustainable development:

Stocks of wealth underpin the opportunities people face, and the process of sustainable development is fundamentally the process of creating, maintaining, and managing wealth. (World Bank, 1997:19)

The need to embark on capacity-restoring activities following environmental degradation is of paramount importance. Without such restoration activities the capacity of the natural capital stock to maintain a secure flow of ecosystem goods and services, which people depend on for life and income generation, is compromised. The question is how to achieve such investments in the best possible way.

Here we wish to provide a sketch of some of the investment opportunities, the low-hanging fruit if you wish, with respect to possible off-site restoration and investment opportunities. By highlighting these opportunities it is not implied that companies do not have, or are absolved from, any on-site responsibilities. A company's first and foremost responsibility towards restoration lies in its on-site activities. However, such activities alone are often inadequate to mitigate; say, for example, a company's water consumption and carbon footprints. This warrants, even necessitates, off-site investment in restoration.

While investments in the restoration of natural capital could take various forms, such as investment in protected areas, various kinds of offset investments and mitigation or bio-banking, here we will consider only payments for ecosystem goods and services. While there is much support of payment for ecosystem services and goods (PES), and while much has been written about it, implementation remains a challenge. This is clearly articulated by the fact that, while value in investing in natural capital can and has been demonstrated in the past, both locally and abroad, capturing this value and then operationalising it is only happening on a small scale (Blignaut et al., 2013). There are many uncertainties embedded within the PES value chain. This value chain 
being: the demonstration of value in the restoration of ecosystem goods and services through say feasibility assessments; capturing the value through the development of, for example a market; and operationalisation by action/implementation. Naturally, with uncertainty comes a certain amount of risk. Risks the private sector are unlikely to take, being, per definition, risk-averse actors. The question therefore is how to reduce this risk and bridge the obvious inertia in developing the PES market.

\section{Literature review}

Historically, what evidence is there with respect to either the success or failure of PES projects? To answer this we conducted a desktop literature review. Three main sources were used to compile the list of case studies:

- A general search on some of the major academic search engines for studies describing PES with particular focus on the special PES edition of the journal Ecological Economics (i.e. volume 69, issue 6).

- A general Google search for PES projects engaging private companies.

- A database, developed by the research team, covering more than 2000 restoration case studies from previous research conducted (see Blignaut, 2008, 2012; Aronson et al., 2010).

These case studies were shortlisted based on: an actual transaction; private sector involvement; and/or mention being made of a fund to incentivise the transaction. This fund could be considered akin to a national natural capital depreciation fund that could act as both recipient of natural capital depreciation allowances, as well as the disbarment of monies in restoration and related activities. Case studies describing theory and concepts were discarded from the list. The final set of case studies was identified as having sufficient material to complete a matrix of questions and is given in Appendix A (Appendix A is available as supplemental data from the article's Taylor \& Francis Online page at http://dx.doi.org/10.1080/0376835X.2014.933699).

The results of the literature review can be divided into four categories based on two continuums, namely:

- the degree to which a market exists, and

- the degree to which the private sector participates in the transaction.

Using this typology, we have identified the four categories presented in Figure 1.

\subsection{An emerging discourse}

From the literature review it is apparent that benefits embedded within restoration and the development of markets and payment mechanisms for ecosystems goods and services are self-evident. Despite this, why the difficulty in the development of the market? Aronson et al. (2010) argued that as markets are social constructs they reflect the will and the intent of the people. The low number of PES transactions in South Africa (Blignaut, 2008; Blignaut et al., 2008; O'Farrell et al., 2011) can be directly attributed to the fact that restoration is not yet viewed by society at large as an activity that reflects its desires, needs or wishes despite their obvious potential benefits. Aronson et al. (2010) further argue from a socio-political point of view that there is a disconnect between restoration researchers and practitioners, and between theory and practice, not to 


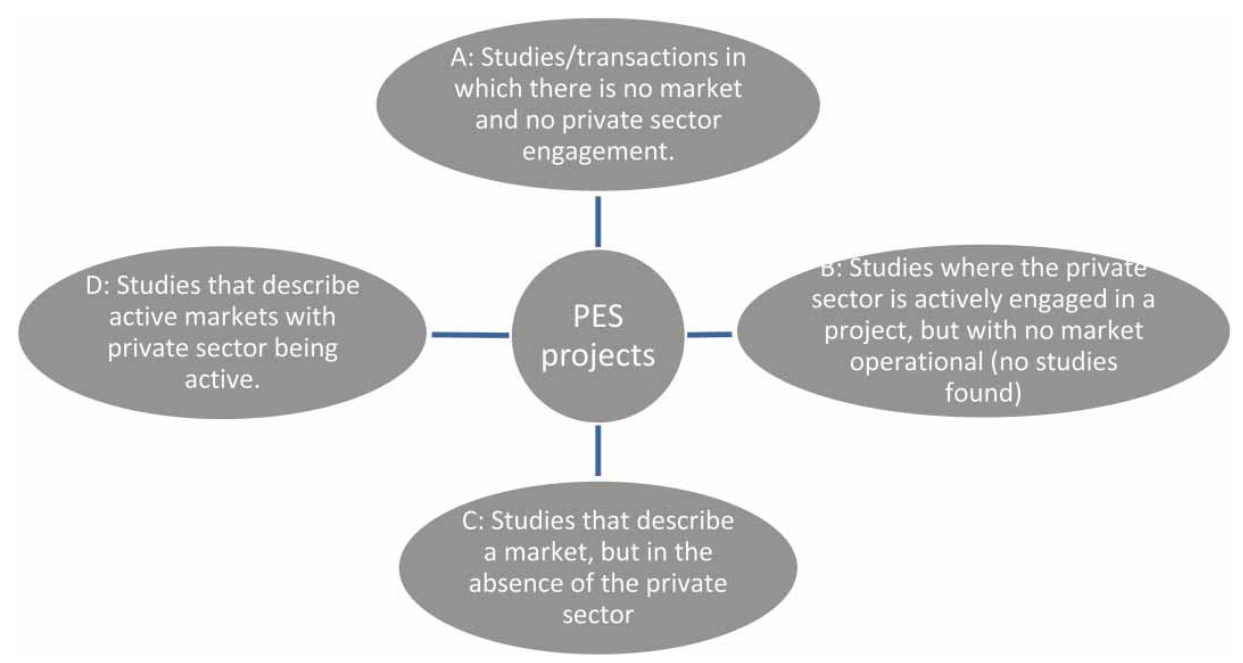

Figure 1: Case studies of PES projects divided into four categories

mention the gap between most investigators in the field and the supposed beneficiaries of eco-restoration that need urgently to be addressed, and redressed.

To bridge the disconnect and take the demonstrated value forward, however, requires a process of value capturing; that is, the realm of market-making. This process involves the active engagement of a wide range of stakeholders, such as the potential buyers and sellers of the service, and then agreeing on the terms and the conditions of the transaction. This could entail aspects such as the specific activity that is involved (i.e. the restoration of erosion gullies) and the specific service it is likely to render (i.e. soil stabilisation and the reduction of silt loads into riparian systems and dams). Agreement has also to be reached on the type and the cost of the intervention, and the payment intervals. Performance management standards have to be set in terms of the agreed-upon activity that could include items such as work hours and the required work load per day, or per term, or the number (and size) of the erosion gullies to be restored. Agreeing on these details has to be based either on evidence or on past research elsewhere. Conditions and the consequences for project failure have also to be agreed upon. Innovative measures, such as those proposed by Van Oosterzee et al.(2012) and Letsoalo et al. (2007), could be considered. These measures refer to the introduction of proven insurance-based hedging principles that would address specific technical and administrative challenges to restoration projects. Project-specific insurance policies and premiums would be negotiated upfront using a simple assessment of risk based on governance quality, the integrity of management plans, liquidity, monitoring and evaluation frameworks, and political acceptability. Other measures could include block pricing and revenue recycling mechanisms that would stimulate the development of the sector.

Only once the value has been captured through a market-making process can the value be realised through the active participation of practitioners and restoration managers that actually implement a project towards some predefined environmental and social outcome. These predefined outcomes are often to be defined during the marketmaking process. What is interesting is that these outcomes could be conflicting, like seeking to encourage job creation and seeking to be as cost-effective and/or efficient 
as possible. Outcomes, preferably, should be defined in such a way that there is no inherent conflict among them.

There are, however, a worryingly small number of these studies where the demonstrated value (through any of a variety of valuation studies) has moved forward. The marketmaking process is onerous, complex and difficult, and is often very costly. It also requires patience, a universal belief in and a concerted effort of all involved taking the demonstrated value and capturing it. Hence, very little of the demonstrated value is actually captured, let alone turned into functioning long-lasting projects.

\subsection{Potential and current PES projects in South Africa}

During the past decade, several PES pre-feasibility studies and other studies that considered the feasibility of PES were undertaken. A selection of some of the potential PES projects is presented in Table 1.

While all the projects listed in Table 1 have some PES potential, none of them have actually been brought to the market at a large scale. For the most part, the reason for this is that funding was made available to investigate the potential; however, the funding and the scope of the respective projects excluded the actual market-making component. The services on offer throughout these potential projects are mostly water flow and quality, carbon, disaster management, biodiversity and renewable energy. While the water, carbon and renewable energy markets should, potentially, attract many private sector buyers, the studies have indicated difficulty in converting the demonstrated value to captured value. Disaster management and biodiversity is, however, more difficult to take to the market. The reasons for this are presented in Table 2.

\section{Discussion and conclusion}

This paper conducted a desktop review of several PES case studies seeking to understand the challenges/obstacles that PES globally is facing. The review pointed toward the barriers to entry and the need to facilitate the market-making process.

While there is much support of PES and much evidence in favour of the concept, implementation remains a challenge. This is clearly demonstrated by the fact that while value in investing in natural capital can and has been demonstrated in the past (Blignaut et al., 2010; Blignaut, 2012; Giordano et al., 2012), capturing this value and then operationalising it is only happening on a small scale. Where this does take place, government agencies such as the Natural Resource Management Programmes and conservation agencies acted as facilitators and implementing agents. This value chain is diagrammatically illustrated in Figure 2. It starts with demonstrating the value, which is largely the subject of scientific enquiry involving a number of disciplines. Thereafter it follows the market development process, which is a process involving the transfer of knowledge and requires a special skill in communication. This involves a large number of stakeholders and the formulation of the transaction -the market-making process. After

capturing the value, the next step is the realisation of that value through operational management.

Given the large uncertainty embedded within this value chain - and with uncertainty, risk - the private sector is unlikely to take the unequivocal lead in the market-making 


\section{Table 1: A selection of potential PES projects in South Africa}

\section{Project site / name}

Organisations involved

1 Olifants / Inkomati river catchment restoration

2 Sand river catchment

3 Crocodile West / Groot Marico river catchments

4 Lephalale

5 Upper-Umzimvubu river catchment

6 Upper-Uthukela river catchment

7 Upper-Orange river catchment

8 Baviaans river catchment

9 Kromme river catchment
DWA; mines; communities

DWA; game reserves; communities

Farmers

DWA; EKZNW; SANBI

DWA; EKZNW; SANBI; water utilities

DWA; TCTA

DWA; Gamtoos Irrigation Board; Nelson Mandela Metro

DWA; Gamtoos Irrigation Board; Nelson Mandela Metro
DWA; mines; communities
Interventions / actions

(Main) Potential services

Water quality and quantity; disaster management; biodiversity; renewable energy

Water quality and quantity; disaster management; biodiversity; renewable energy

plants

Invasive alien plant clearing

Water quality and quantity; disaster management

Bush thinning

Erosion control, re-vegetation, invasive alien plant clearing

Renewable energy

Water quality and quantity; carbon sequestration; biodiversity; sediment reduction; disaster management

Erosion control, Revegetation, invasive alien plant clearing

Erosion control, invasive alien plant clearing

Erosion control, re-vegetation, invasive alien plant clearing

Erosion control, re-vegetation, invasive alien plant clearing
Water quality and quantity; carbon sequestration; biodiversity; sediment reduction; disaster management

Water quality and quantity; carbon sequestration; biodiversity; sediment reduction; disaster management

Water quality and quantity; Carbon sequestration; Disaster management

DWA internal strategic perspectives; Mander et al. reports

DWA internal strategic perspectives; Mander et al. reports

DWA internal strategic perspectives; Mander et al. reports

DWA internal strategic perspectives

Water quality and quantity; carbon sequestration; disaster management
DWA internal strategic perspectives; Dini wetland study; WRC research reports

DWA internal strategic perspectives; WRC research reports

DWA internal strategic perspectives

WRC research reports

DWA internal strategic perspectives; Mander et al. reports renewable energy 
10 Berg / Breede river catchments

11 Agulhas plains

12 Beaufort West

13 Sub-tropical thicket restoration
DWA; TCTA; City of Cape Invasive alien plant clearing

Town

DWA; Agulhas Biodiversity

Initiative; town councils

DWA; town council

Invasive alien plant clearing

Invasive alien plant clearing

Re-vegetation
Water quality and quantity; disaster management; renewable energy

Water quality and quantity; disaster

management; renewable energy

Water quality and quantity; disaster management; renewable energy

Carbon; biodiversity
DWA internal strategic perspectives; Western Cape Systems Analysis

DWA internal strategic perspectives; WRC research reports

DWA internal strategic perspectives; WRC research reports

PDD, publications by Cowling and Mills

Notes: DBSA, Development Bank of Southern Africa; DWA, Department of Water Affairs and Forestry; EKZNW, Ezemvelo KwaZulu-Natal Wildlife; PDD, project design document; SANBI, South African National Biodiversity Institute; TCTA, Trans-Caledon Tunnel Authority; WRC, Water Research Commission. 
Table 2: Reasons for difficulties in realising markets

\begin{tabular}{|c|c|}
\hline Market & Reasons for difficulties \\
\hline Water & $\begin{array}{l}\text { - Link between clearing invasive alien plants and water runoff/baseflow, yield is not } \\
\text { always certain and further empirical evidence of these links is required } \\
\text { - Only be done through well-monitored projects to calibrate the hydrological models } \\
\text { - Restoration almost always contribute to baseflow, yet baseflow's contribution } \\
\text { towards yield is limited, and baseflow is therefore under-appreciated in terms of its } \\
\text { contribution to water security, and maintaining ecological processes } \\
\text { - Strong vested interests in the built environment protecting the dam construction } \\
\text { industry }\end{array}$ \\
\hline Carbon & $\begin{array}{l}\text { - The process of verification is costly, complex and time-consuming } \\
\text { - The potential for carbon offsetting exists, but the carbon/hectare offsetting potential } \\
\text { in South Africa is less than in the tropics due to the country's arid nature } \\
\text { - The unit cost to bring a ton of carbon to the market is higher than in the tropics } \\
\text { - The above implies that South Africa would require projects of significant scale to } \\
\text { make the projects viable, implying the collaboration of a large number of land users/ } \\
\text { owners, making the projects very complex }\end{array}$ \\
\hline Renewable energy & $\begin{array}{l}\text { - Technologies towards the use of biomass for renewable power generation } \\
\text { (electricity, charcoal, etc.) exist but using invasive alien species on a large scale } \\
\text { combining various different land-owners/users remains untested } \\
\text { - Once demonstrated how multiple land-owners/users can combine their efforts } \\
\text { towards this objective, the possibility exists to generate as much as } 700 \mathrm{MW} \\
\text { (Blignaut et al. 2008) }\end{array}$ \\
\hline $\begin{array}{l}\text { Disaster } \\
\text { management }\end{array}$ & $\begin{array}{l}\text { - During times of extreme events (droughts, floods and outbreak of pests) the quality of } \\
\text { the stock of natural capital acts as an important buffer, mitigating the effects of such } \\
\text { an event. Investment in natural capital and the restoration thereof could, therefore, be } \\
\text { seen as a form of insurance policy. This, however, is not yet a readily accepted form } \\
\text { of insurance policy }\end{array}$ \\
\hline Biodiversity & $\begin{array}{l}\text { - The local and global biodiversity markets are not yet well developed } \\
\text { - Markets that do exist often make use of conservation easements } \\
\text { - However, this has not yet taken-off in South Africa. The reason for this is that } \\
\text { deriving a measurable, marketable, biodiversity metric still evades us }\end{array}$ \\
\hline
\end{tabular}

process. The private sector is most likely to be involved in two aspects within the value chain, namely:

- as buyers of services and hence involved as party to the market-making process (i.e. the process of capturing the value); and

- as service providers with respect to operational management (i.e. the provision of restoration and natural resource management services). This is more than likely services to be performed by small private restoration enterprises in conjunction with the National Natural Resource Management Programmes and other similar restoration initiatives.

These two facets, however, are lower order facets within the PES value chain. To unlock these two activities requires, at a higher level, a risk-taking facility that would, among other factors: conduct research into the identification of PES projects by conducting a number of feasibility assessments; provide both risk as well as bridging finance to 
Operations management

Transaction formation/market making: Process of society-wide engagement

Knowledge transfer Art of communication Semantics matter

Knowledge generation: Process of scientific enquiry

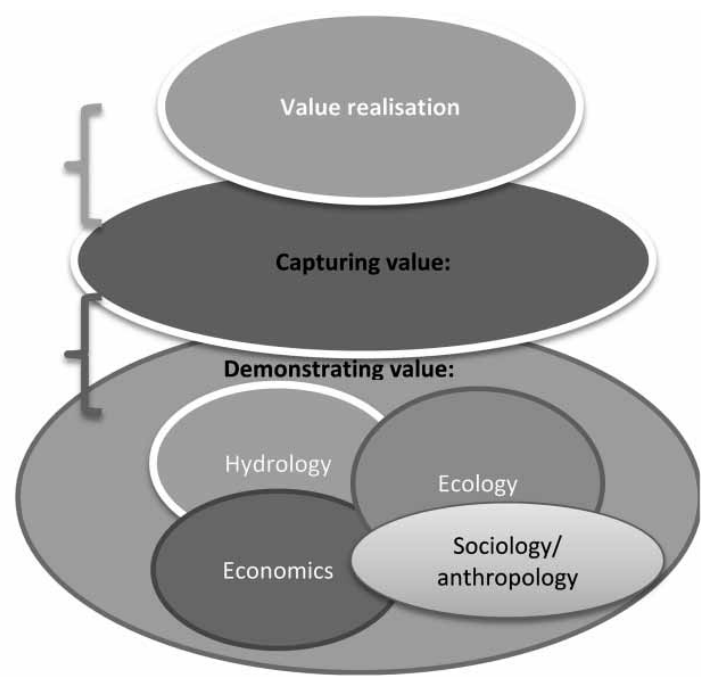

Figure 2: The ecosystem marketisation value chain

embark on pilot projects that demonstrate the entire value chain in action; make available a pool of funds that could be accessed by the restoration enterprises and PES development agents; and establish a support service providing specialist PES development services.

Such a risk-taking facility could have the potential to mobilise private sector finance into PES projects by playing a catalytic role through demonstration, participation and risk mitigation, and in the process reduce the transaction cost of and the operational risk related to restoration and payments for ecosystem goods and services projects.

From the discussion above it should be self-evident that there is a very important role to play by a risk-taking facility, such as a PES fund, in assisting the development of the PES industry in the country. The fund has the potential to mobilise private sector finance into PES projects by playing a catalytic role through demonstration, participation and risk mitigation. This fund could, in part, play the role of South Africa's natural capital depreciation fund whereby disbursements from it can be used to replenish the natural capital stock. Such replenishment is essential in maintaining the natural capital stock intact, which is a necessary condition to maintain constant income or benefits flows. Compromising the quality and the quantity of the country's natural stock implies compromising its future benefit stream. Investing in its natural capital stock, however, is an investment towards sustainability.

\section{Supplemental data}

Please see Appendix A for a summary of the results of the literature review.

\section{References}

Aronson, J, Blignaut, JN, Milton, S, Le Maitre, D, Esler, K, Limouzin, A, Fontaine, C, De Wit, MP, Mugido, W, Prinsloo, P, Van der Elst, L \& Lederer, N, 2010. Why restore? A meta-analysis of 
recent papers (2000-2008) in Restoration Ecology and 12 other scientific journals. Restoration Ecology 18(2), 143-54.

Blignaut, JN, 2008. An inventory of current and potential projects and markets for payments for ecosystem services. Report prepared for the Katoomba Group. www.katoombagroup.org/ regions/africa/documents/2008_SA_Inventory.pdf Accessed 14 September 2013.

Blignaut, JN, 2012. How ecosystem-based restoration can yield a double dividend of adaptation to climate change and enhancement of ecosystem services. UNEP DEPI Ecosystem Services Economics (ESE) Working Paper Series, Paper No. 18. depi.unep.org/index.php? option $=$ com_content\&view $=$ article\&id=133\&Itemid=34 Accessed 20 March 2012.

Blignaut, JN, Marais, M, Rouget, M, Mander, M, Turpie, J, Klassen, T \& Preston, G, 2008. Making markets work for people and the environment: Combating poverty and environmental degradation on a single budget while delivering real services to real people. The Second Economy Strategy Project, an initiative of the Presidency, TIPS, Pretoria.

Blignaut, JN, Mander, M, Schulze, R, Horan, M, Dickens, C, Pringle, C, Mavundla, K, Mahlangu, I, Wilson, A, McKenzie, M \& McKean, S, 2010. Restoring and managing natural capital towards fostering economic development: Evidence from the Drakensberg, South Africa. Ecological Economics 69, 1313-23.

Blignaut, J, Aronson, J \& De Groot, D, 2013. Restoration of natural capital: A key strategy on the path to the quest for sustainability. Ecological Engineering 65, 54-61.

Costanza, R \& Daly, H, 1992. Natural capital and sustainable development. Conservation Biology $6,37-46$.

Daly, HE, 1996. Beyond Growth. The Economics of Sustainable Development. Beacon Press, Boston.

El Serafy, S, 1989. The proper calculation of income from depletable natural resources. In Ahmad, YJ, El Serafy, S \& Lutz, E (Eds.), Environmental Accounting for Sustainable Development. World Bank, Washington, DC.

Giordano, T, Blignaut, JN \& Marais, C, 2012. Natural resource management - an employment catalyst: The case of South Africa. Development Bank of Southern Africa Working Paper, Midrand.

Hicks, J, 1946. Value and Capital. Oxford University Press, Oxford.

Letsoalo, A, Blignaut, J, de Wet, T, de Wit, M, Hess, S, Tol, RSJ \& van Heerden, J, 2007. Triple dividends of water consumption charges in South Africa. Water Resources Research 43, W05412.

O’Farrell, P, Le Maitre, D, De Lange, W, Reyers, B, Blignaut, J, Milton, S, Atkinson, D, Egoh, B, Maherry, A, Colvin, C \& Cowling, R, 2011. The possibilities and pitfalls presented by a pragmatic approach to ecosystem service valuation in an arid biodiversity hotspot. Journal of Arid Environments 75, 612-23.

Stern, DI, 1997. Capital theory approach to sustainability. Journal of Economic Issues XXXI (1), $145-73$.

Van Oosterzee, P, Blignaut, J \& Bradshaw, CJA, 2012. iREDD hedges against avoided deforestation's unholy trinity. Conservation Letters 5(4), 266-73.

World Bank, 1997. Expanding the measures of wealth. Environmentally Sustainable Development Studies and Monograph Series No. 17, World Bank, Washington, DC. 


\section{Appendix A}

Table A: Results of the literature review

\begin{tabular}{|c|c|c|c|c|c|c|c|c|}
\hline Authors & Country & Year & Ecosystem & $\begin{array}{l}\text { Services } \\
\text { traded }\end{array}$ & Monetary value & $\begin{array}{l}\text { Mechanism (how transaction } \\
\text { took place) }\end{array}$ & $\begin{array}{l}\text { Incentive (what money and } \\
\text { where does it come from) }\end{array}$ & $\begin{array}{l}\text { Private Sector } \\
\text { involvement }\end{array}$ \\
\hline \multicolumn{9}{|c|}{ A: No market yet, but under development; no private sector engagement yet } \\
\hline $\begin{array}{l}\text { Blignaut, et } \\
\text { al. }\end{array}$ & $\begin{array}{l}\text { South } \\
\text { Africa }\end{array}$ & 2010 & Grasslands & $\begin{array}{l}\text { Water, } \\
\text { carbon, } \\
\text { biodiversity }\end{array}$ & R5-R90mil/a & Under investigation & $\begin{array}{l}\text { Various potential actors } \\
\text { (government, conservancies } \\
\text { and private) }\end{array}$ & $\begin{array}{l}\text { None; possibilities } \\
\text { indicated }\end{array}$ \\
\hline $\begin{array}{l}\text { Fedrigotti, } \\
\text { et al. }\end{array}$ & Italy & 2011 & $\begin{array}{l}\text { Chestnut } \\
\text { orchard }\end{array}$ & $\begin{array}{l}\text { Cultural } \\
\text { services }\end{array}$ & Not indicated & $\begin{array}{l}\text { Generally linked to input use } \\
\text { (input-based)/tourism income }\end{array}$ & Not indicated & Not indicated \\
\hline $\begin{array}{l}\text { Börner, et } \\
\text { al. }\end{array}$ & Brazil & 2009 & $\begin{array}{l}\text { Tropical } \\
\text { forest }\end{array}$ & Carbon & $\begin{array}{l}\text { Avg } R \$ 2703 / \mathrm{ha} \\
\text { protected }\end{array}$ & $\begin{array}{l}\text { Indicated as a massive } \\
\text { challenge }\end{array}$ & None indicated & None indicated \\
\hline \multicolumn{9}{|c|}{ B: No market yet, but under development; private sector engaged } \\
\hline \multicolumn{9}{|l|}{ None found } \\
\hline \multicolumn{9}{|c|}{ C: Active market; no private sector engagement yet } \\
\hline $\begin{array}{l}\text { Muñoz- } \\
\text { Piña, et al. }\end{array}$ & Mexico & 2003 & Forests & Water & $\begin{array}{l}\text { M\$200 million } \\
\text { (US\$18.2 } \\
\text { million)/annum } \\
\text { (increased to } \\
\text { M\$300 million (US } \\
\$ 27.3 \text { million) in } \\
2004 \text { ) }\end{array}$ & $\begin{array}{l}\text { Direct payments to landowners } \\
\text { with primary forest cover in } \\
\text { good state of conservation }\end{array}$ & $\begin{array}{l}\text { Payment to participating } \\
\text { forest owners }\end{array}$ & None indicated \\
\hline $\begin{array}{l}\text { Sommervill } \\
\text { e, et al. }\end{array}$ & Madagascar & 2010 & Forests & $\begin{array}{l}\text { Biodiversity, } \\
\text { sustainable } \\
\text { benefits }\end{array}$ & $\begin{array}{l}\sim \$ 8500 \text { is } \\
\text { distributed among } \\
\text { current } 10 \\
\text { communities } \\
\text { annually, annual } \\
\text { membership fee } \\
\text { (\$0.30 to } \$ 7), \text { a } \\
\text { one-time joining fee } \\
\text { (\$0.50 and } \$ 2 \text { ) }\end{array}$ & $\begin{array}{l}\text { Payment to each community } \\
\text { used to purchase in-kind } \\
\text { incentives }\end{array}$ & $\begin{array}{l}\text { Durrell Wildlife Conservation } \\
\text { Trust (Durrell) }\end{array}$ & Donor-driven \\
\hline Gee, C. & China & $\begin{array}{l}2000- \\
2010\end{array}$ & Forests & $\begin{array}{l}\text { Biodiversity, } \\
\text { carbon } \\
\text { sequestration, }\end{array}$ & $\begin{array}{l}\text { \$43billion (total } \\
\text { budget for } 10 \text { years) }\end{array}$ & Allowances paid to farmers & Government programme & Government-driven \\
\hline
\end{tabular}




\begin{tabular}{|c|c|c|c|c|c|c|c|c|}
\hline Authors & Country & Year & Ecosystem & $\begin{array}{l}\text { Services } \\
\text { traded }\end{array}$ & Monetary value & $\begin{array}{l}\text { Mechanism (how transaction } \\
\text { took place) }\end{array}$ & $\begin{array}{l}\text { Incentive (what money and } \\
\text { where does it come from) }\end{array}$ & $\begin{array}{l}\text { Private Sector } \\
\text { involvement }\end{array}$ \\
\hline & & & & $\begin{array}{l}\text { hydrological } \\
\text { regulation }\end{array}$ & & & & \\
\hline \multicolumn{9}{|c|}{ D: Active market; private sector engaged } \\
\hline $\begin{array}{l}\text { Maiziere, et } \\
\text { al. }\end{array}$ & $\begin{array}{l}\text { Democratic } \\
\text { Republic of } \\
\text { Congo }\end{array}$ & 2011 & Forests & Carbon & $\begin{array}{l}240040 \text { us\$ (2009- } \\
2017)\end{array}$ & $\begin{array}{l}\text { A local implementing agent } \\
\text { acting as facilitating agent, } \\
200 \text { seasonal and } 30 \text { full-time } \\
\text { jobs }\end{array}$ & $\begin{array}{l}\text { Financial support - Belgian } \\
\text { Development Cooperation, } \\
\text { Sales of carbon }\end{array}$ & $\begin{array}{l}\text { Private sector - } \\
\text { international } \\
\text { companies }\end{array}$ \\
\hline $\begin{array}{l}\text { Asquith, et } \\
\text { al. }\end{array}$ & Bolivia & $\begin{array}{l}2003 \\
\text { onwar } \\
\text { ds }\end{array}$ & $\begin{array}{l}\text { Watershed, } \\
\text { Forest }\end{array}$ & Water & $\begin{array}{l}\text { Start-up } \\
(\sim \text { US\$40,000), } \\
\text { running transaction } \\
\text { costs ( US\$3000 } \\
\text { per year over three } \\
\text { years). }\end{array}$ & $\begin{array}{l}\text { Annual quid pro quo in-kind } \\
\text { compensations facilitated by a } \\
\text { local NGO, Fundación Natura } \\
\text { Bolivia }\end{array}$ & $\begin{array}{l}\text { An international conservation } \\
\text { donor buying services, } \\
\text { External donors, Downstream } \\
\text { irrigators }\end{array}$ & Downstream farmers \\
\hline $\begin{array}{l}\text { Clements, et } \\
\text { al. }\end{array}$ & Cambodia & 2010 & Wildlife & $\begin{array}{l}\text { Wildlife } \\
\text { protection, } \\
\text { eco-tourism }\end{array}$ & $\begin{array}{l}\text { Approx } \$ 120-\$ 160 \\
\text { per family } \\
\text { participating } \\
\text { Avg of } \$ 1200 / \max \\
\text { of } \$ 4000-\$ 6000 \text { per } \\
\text { village }\end{array}$ & $\begin{array}{l}\text { Government and NGO } \\
\text { instituted a series of pilot PES } \\
\text { programs managed by elected } \\
\text { village committees/Wildlife } \\
\text { Conservation Society }\end{array}$ & $\begin{array}{l}\text { Fees paid by tourists / selling } \\
\text { of goods / Government }\end{array}$ & Yes; tourists \\
\hline Gong, et al. & China & $\begin{array}{l}2006- \\
2035\end{array}$ & Forests & $\begin{array}{l}\text { Sequestering } \\
\text { carbon, } \\
\text { enhancing } \\
\text { biodiversity, } \\
\text { reducing soil } \\
\text { erosion, } \\
\text { improving } \\
\text { local } \\
\text { livelihoods } \\
\end{array}$ & $\begin{array}{l}\text { Expected total } \\
\text { revenue: approx } \\
\text { US\$ } 5.5 \text { million }\end{array}$ & Paid as salaries & $\begin{array}{l}\text { Subsidised loans and } \\
\text { government funding }\end{array}$ & $\begin{array}{l}\text { Yes (local forest } \\
\text { companies) }\end{array}$ \\
\hline Pagiola, S. & Costa Rica & 2006 & Forests & $\begin{array}{l}\text { Water, } \\
\text { biodiversity } \\
\text { conservation, } \\
\text { carbon } \\
\text { sequestration } \\
\end{array}$ & $\begin{array}{l}\text { US\$5 million (water } \\
\text { services), } \\
\text { US\$5 million } \\
\text { (biodiversity) }\end{array}$ & FONAFIFO & $\begin{array}{l}\text { 3.5\% of revenue of fossil fuel } \\
\text { sales tax / World Bank loan / } \\
\text { Grant from Global } \\
\text { Environment Facility / } \\
\text { German aid }\end{array}$ & $\begin{array}{l}\text { Yes (provision of water } \\
\text { services - contribute to } \\
\text { FONAFIFO } \\
\text { administration costs) }\end{array}$ \\
\hline $\begin{array}{l}\text { Blackman, et } \\
\text { al. }\end{array}$ & Costa Rica & 2010 & Forests & $\begin{array}{l}\text { Biodiversity, } \\
\text { carbon } \\
\text { sequestration, } \\
\text { scenic beauty, }\end{array}$ & $\begin{array}{l}\text { Annual per hectare } \\
\text { payments approx } \\
\text { US\$64 in } 2006\end{array}$ & FONAFIFO & $\begin{array}{l}\text { Tax revenue supplemented } \\
\text { since } 2006 \text { by revenue from a } \\
\text { national tariff on water-use, } \\
\text { loans, and a variety of users }\end{array}$ & $\begin{array}{l}\text { Yes - hydroelectric } \\
\text { sector (as part of user } \\
\text { financing) }\end{array}$ \\
\hline
\end{tabular}




\begin{tabular}{|c|c|c|c|c|c|c|c|c|}
\hline Authors & Country & Year & Ecosystem & $\begin{array}{l}\text { Services } \\
\text { traded }\end{array}$ & Monetary value & $\begin{array}{l}\text { Mechanism (how transaction } \\
\text { took place) }\end{array}$ & $\begin{array}{l}\text { Incentive (what money and } \\
\text { where does it come from) }\end{array}$ & $\begin{array}{l}\text { Private Sector } \\
\text { involvement }\end{array}$ \\
\hline & & & & $\begin{array}{l}\text { hydrological } \\
\text { benefits }\end{array}$ & & & & \\
\hline $\begin{array}{l}\text { Corbera, et } \\
\text { al. }\end{array}$ & $\begin{array}{l}\text { i) } \\
\text { Guatemala }\end{array}$ & 2007 & Forests & $\begin{array}{l}\text { Biodiversity } \\
\text { conservation, } \\
\text { watershed } \\
\text { conservation, } \\
\text { carbon dioxide } \\
\text { fixation, } \\
\text { protecting and } \\
\text { managing the } \\
\text { hydrographica } \\
\text { I basin, } \\
\text { sustainable } \\
\text { agricultural } \\
\text { practices, low } \\
\text { impact } \\
\text { ecotourism, } \\
\text { sustainable } \\
\text { forest } \\
\text { management }\end{array}$ & US\$17.86/ha/year & $\begin{array}{l}\text { FUNDAECO administers the } \\
\text { Reserve on behalf of the } \\
\text { Guatemalan State }\end{array}$ & $\begin{array}{l}\text { An increase in the water tariff } \\
\text { of US\$0.20/month }\end{array}$ & $\begin{array}{l}\text { Yes (Empresa } \\
\text { Hidroele'ctrica del } \\
\text { Atla'ntico (HEDASA), a } \\
\text { local hydroelectricity } \\
\text { company) }\end{array}$ \\
\hline
\end{tabular}




\begin{tabular}{|c|c|c|c|c|c|c|c|c|}
\hline Authors & Country & Year & Ecosystem & $\begin{array}{l}\text { Services } \\
\text { traded }\end{array}$ & Monetary value & $\begin{array}{l}\text { Mechanism (how transaction } \\
\text { took place) }\end{array}$ & $\begin{array}{l}\text { Incentive (what money and } \\
\text { where does it come from) }\end{array}$ & $\begin{array}{l}\text { Private Sector } \\
\text { involvement }\end{array}$ \\
\hline & iii) Mexico & 2007 & Forests & $\begin{array}{l}\text { Biodiversity } \\
\text { conservation, } \\
\text { watershed } \\
\text { conservation, } \\
\text { carbon dioxide } \\
\text { fixation }\end{array}$ & $\begin{array}{l}\text { US\$3.27/tCO2eq, } \\
\text { (from which a } 66.6 \\
\text { per cent } \\
\text { (US\$2.18/tCO2eq) } \\
\text { is allocated directly } \\
\text { to farmers) }\end{array}$ & $\begin{array}{l}\text { A total of } 4738 \text { ha under } \\
\text { reforestation and conservation } \\
\text { activities funded by several } \\
\text { investors in for VERs to offset } \\
\text { their greenhouse gas emissions }\end{array}$ & $\begin{array}{l}\text { Funded by several } \\
\text { investors - The Carbon } \\
\text { Neutral Company, Tetra Pak, } \\
\text { International Automobile } \\
\text { Federation and The World } \\
\text { Bank }\end{array}$ & $\begin{array}{l}\text { Yes (reforestation and } \\
\text { conservation activities } \\
\text { funded by several } \\
\text { investors-The Carbon } \\
\text { Neutral Company, Tetra } \\
\text { Pak, International } \\
\text { Automobile Federation } \\
\text { and The World Bank) }\end{array}$ \\
\hline & iv) Belize & 2007 & Forests & $\begin{array}{l}\text { Biodiversity } \\
\text { conservation, } \\
\text { watershed } \\
\text { conservation, } \\
\text { carbon dioxide } \\
\text { fixation }\end{array}$ & $\begin{array}{l}\text { US\$0.25/tCO2eq } \\
\text { (approximate } \\
\text { undiscounted price) }\end{array}$ & $\begin{array}{l}\text { The Nature } \\
\text { Conservancy (TNC) and } \\
\text { Winrock International brokered } \\
\text { an agreement with investors } \\
\text { and prepared carbon } \\
\text { sequestration scenarios and } \\
\text { forest management plans }\end{array}$ & $\begin{array}{l}\text { Investors (include a } \\
\text { consortium of US and } \\
\text { Canadian energy utilities). }\end{array}$ & $\begin{array}{l}\text { Yes (The project has } \\
\text { involved one } \\
\text { international } \\
\text { conservationist } \\
\text { organization-The } \\
\text { Nature Conservancy } \\
\text { (TNC)-and one } \\
\text { consultancy firm- } \\
\text { Winrock International; } \\
\text { Investors include a } \\
\text { consortium of US and } \\
\text { Canadian energy } \\
\text { utilities) }\end{array}$ \\
\hline Turpie, et al. & $\begin{array}{l}\text { South } \\
\text { Africa }\end{array}$ & 2008 & $\begin{array}{l}\text { Riparian } \\
\text { systems, } \\
\text { mountain } \\
\text { catchments }\end{array}$ & Water & $\begin{array}{l}\text { An annual budget } \\
\text { of more than } \\
\text { R2 billion }\end{array}$ & $\begin{array}{l}\text { WfW control invasive alien } \\
\text { plant infestation; creates jobs; } \\
\text { pays salaries }\end{array}$ & $\begin{array}{l}\text { Generated through poverty } \\
\text { relief programmes (the } \\
\text { Reconstruction and } \\
\text { Development Programme, } \\
\text { the Special Public Works } \\
\text { Programmes, which evolved } \\
\text { to become the Expanded } \\
\text { Public Works Programme); } \\
\text { DWAF includes a water } \\
\text { resource management fee in } \\
\text { the water tariff charged to } \\
\text { consumers }\end{array}$ & $\begin{array}{l}\text { Yes; through the } \\
\text { trading account }\end{array}$ \\
\hline
\end{tabular}




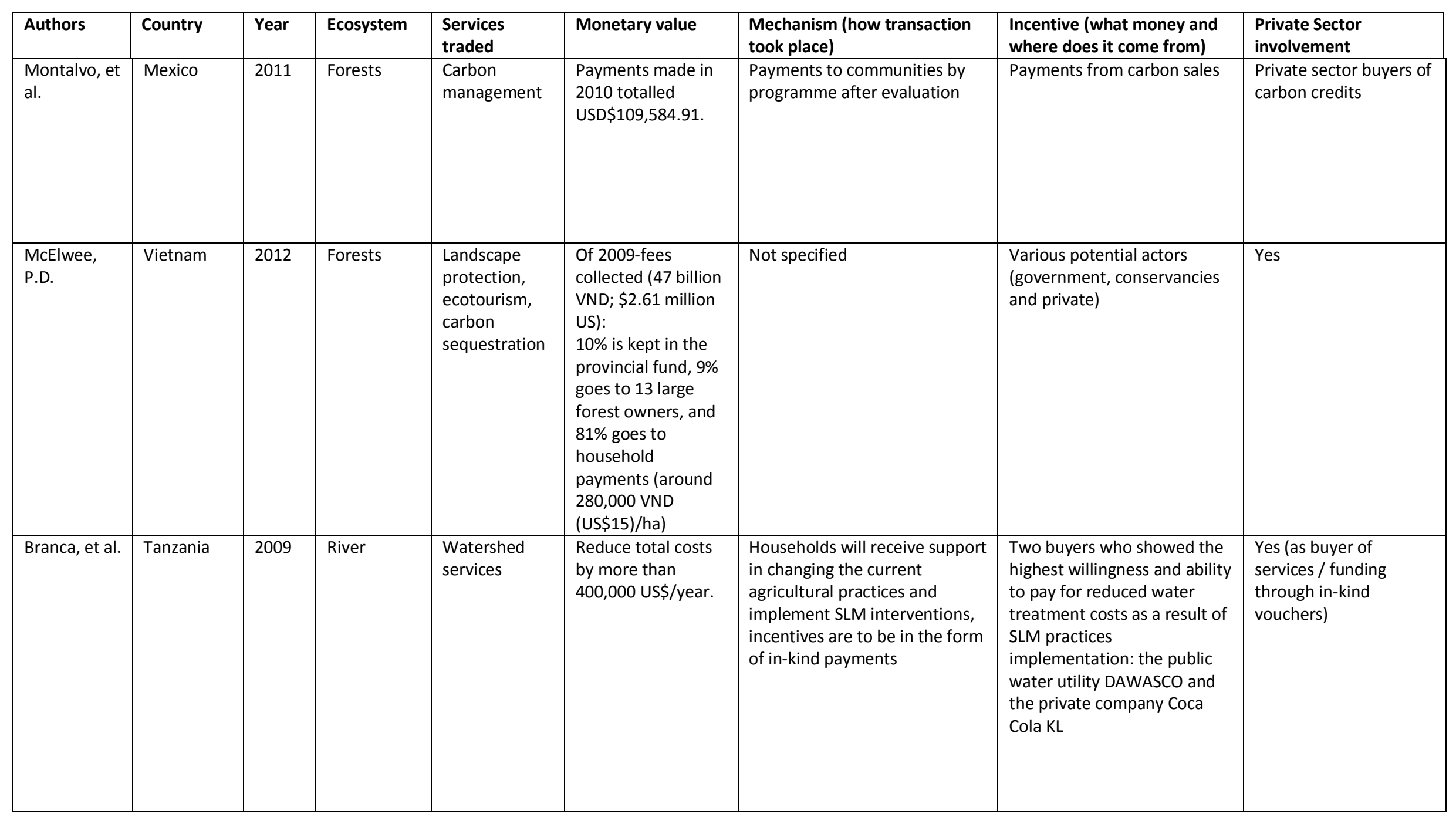




\begin{tabular}{|c|c|c|c|c|c|c|c|c|}
\hline Authors & Country & Year & Ecosystem & $\begin{array}{l}\text { Services } \\
\text { traded }\end{array}$ & Monetary value & $\begin{array}{l}\text { Mechanism (how transaction } \\
\text { took place) }\end{array}$ & $\begin{array}{l}\text { Incentive (what money and } \\
\text { where does it come from) }\end{array}$ & $\begin{array}{l}\text { Private Sector } \\
\text { involvement }\end{array}$ \\
\hline Frost et, al. & Zimbabwe & 2008 & Wildlife & $\begin{array}{l}\text { Wildlife } \\
\text { protection, } \\
\text { eco-tourism }\end{array}$ & $\begin{array}{l}\text { US\$20 million of } \\
\text { transfers to } \\
\text { participating } \\
\text { communities }\end{array}$ & $\begin{array}{l}\text { CAMPFIRE markets access to } \\
\text { wildlife in their district to safari } \\
\text { operators }\end{array}$ & $\begin{array}{l}\text { The District Councils pay the } \\
\text { communities a dividend } \\
\text { according to an agreed } \\
\text { formula. }\end{array}$ & Yes, hunters \\
\hline
\end{tabular}

Notes: CAMPFIRE, Communal Areas Management Programme for Indigenous Resources; DWAF, Department of Water Affairs and Forestry; FONAFIFO, National Funding Forestry Fund; FUNDAECO, Fundacio'n Para el Ecodesarrollo y la Conservacio'n; NGO, non-governmental organisation; PASOLAC, Programme for Sustainable Agriculture on the Hillsides of Central America; PES, payment for ecosystem services and goods; SLM, sustainable AQ7 land management; VER, voluntary emission reduction; WfW, Working for Water. 